\title{
Regulatory challenges reduce opportunities for horticultural biotechnology
}

\author{
Keith Redenbaugh \\ Alan McHughen
}

$\nabla$

\begin{abstract}
Development of transgenic horticultural crops has slowed significantly in recent years for several reasons, including the European Union's moratorium on biotech approvals, lack of tolerance levels for adventitious (accidental) presence in food and seed, significantly increased regulatory costs and decreased acceptance by food wholesalers and retailers. While
\end{abstract} progress in the United States has slowed and approvals in the European Union stopped, some countries such as China continue to develop biotech products for their internal and external markets that will affect the U.S. and California industry. Within a few years, China will emerge as the leader in biotech horticultural crops.

$\mathrm{H}$ orticultural crops were the first biotech crops commercialized in the United States, beginning with Calgene's ground-breaking Flavr Savr tomato in 1994, followed in 1995 by Asgrow's virus-resistant squash and DNA Plant Technology's Endless Summer tomato. The Flavr Savr tomato, with its superior flavor and shelf life, was well received by consumers, garnered repeat purchases and demonstrated that consumers were receptive to fresh produce labeled as genetically engineered (Bruening and Lyons 2000). In 1996, Zeneca launched a biotech processing-tomato product that from 1999 to 2000 was the best-selling tomato paste (puree) in the United Kingdom. The paste reduced processing costs and resulted in a $20 \%$ lower price. However,

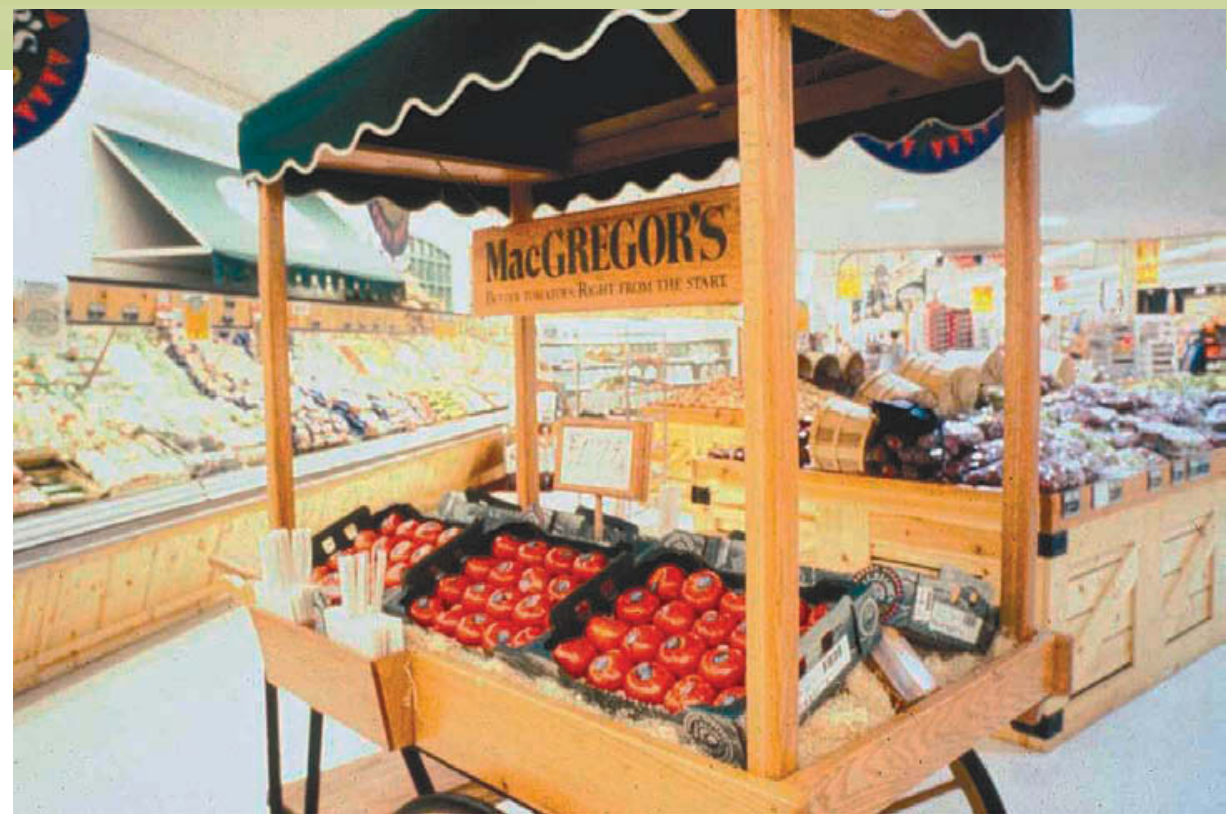

Calgene's Flavr Savr tomato was successfully sold under the MacGregor's brand in the United States. Consumers were willing to purchase it, but the product was not financially profitable and was ultimately withdrawn from the market.

despite their consumer benefits and initial market acceptance, none of these tomato products were financial successes and none are being sold today. In the first instance, production and distribution costs of the Flavr Savr proved prohibitive. In the second case, Zeneca decided not to continue growing the tomatoes in California and shipping the paste to the United Kingdom. When Zeneca ran into the European moratorium, they were unable to get approval for growing the tomatoes in Europe. Once the supply of the tomato paste was exhausted, the product disappeared from the grocery store shelves.

These early products of horticultural biotechnology are often overlooked because of the huge successes of biotech field crops such as feed corn, soybeans and cotton. Since their introduction in 1996, biotech field crops have quickly gained wide acceptance by farmers and were grown on more than 167 million acres worldwide in 2003, primarily in the United States, Canada, Argentina, Brazil and China (James 2003) (fig. 1). India recently approved biotech cotton and Brazil approved biotech soybeans, for a total of 18 countries that have approved commercial field production of biotech crops. All of these crops are designed for pest and weed control, with either insect or herbicide resistance. As a result, sales of conventional agricultural pesticides declined $7.4 \%$ in 2000, while biotech-based varieties jumped 12.9\% (Schmitt 2002). The worldwide value of all seed business (biotech plus conventional seed) rose from $\$ 15.3$ billion in 1996 to $\$ 16.7$ billion in 2001, but the value of conventional seed fell during the same period from $\$ 14.9$ billion to $\$ 13.4$ billion, indicating a healthy value of $\$ 3.3$ billion in 2001 for biotech seed worldwide. Although the European Union (E.U.) moratorium on new registrations has affected introduction of the newest biotech field crops, the utilization of current products is increasing.

The success of biotech field crops is in sharp contrast to restricted commercial opportunities for biotech fruits and vegetables. There are few examples of transgenic horticultural crops that are currently being grown and marketed successfully: virus-resistant squash is planted on a small acreage in the south- 
east United States, and virus-resistant papaya has been grown in Hawaii since 1998 (Ferreira et al. 2002; see sidebar, page 92). Whereas Zeneca was able to obtain food approval for its tomato in the United Kingdom in 1995 (as did Calgene for the Flavr Savr tomato), no food approvals have been allowed in the European Union since an unofficial moratorium was imposed in 1998, in effect stopping the import or cultivation of any new biotech crops. Japan has also restricted imports of biotech foods, requiring suppliers to obtain food and environmental approvals prior to importation. Commodity organizations, shippers-packers and grocery chains in the United States have also been reluctant to introduce new biotech varieties and foods because of logistical difficulties in segregating food for export markets to Europe and Japan. For example, even though it resulted in a significant reduction in insecticide use, Monsanto's insect- and virus-resistant New Leaf potato is no longer available because a major processor (McCain Foods) and fast-food chain (McDonald's) prohibited their suppliers from using this variety (Cornell Cooperative Extension 2003).

Gianessi et al. (2002) calculated that there would have been 1 billion pounds of yield gain in 2001 and a reduction of 1.5 million pounds of pesticide active ingredients applied if growers

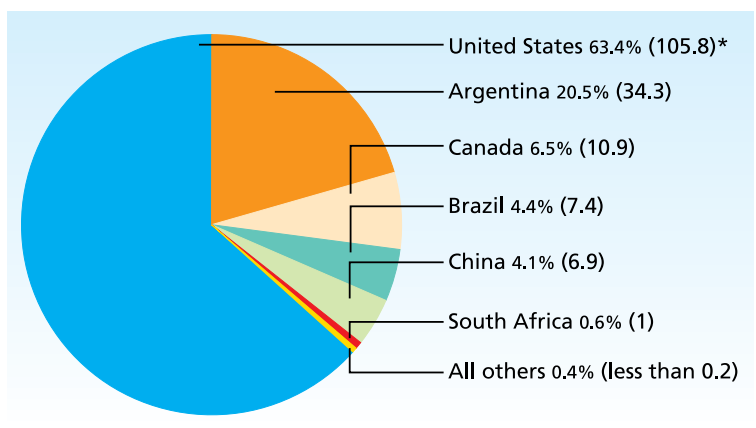

Fig. 1. Percentage of commercialized transgenic crops planted by countries, out of total global acreage (167 million) in 2003. (*Numbers in parenthesis are million acres.) "All others" includes countries that planted 200,000 acres or less: Australia, Mexico, Spain, Romania, Bulgaria, Germany, Uruguay, Indonesia, India, Colombia, Honduras, Philippines and France. Source: James 2003.

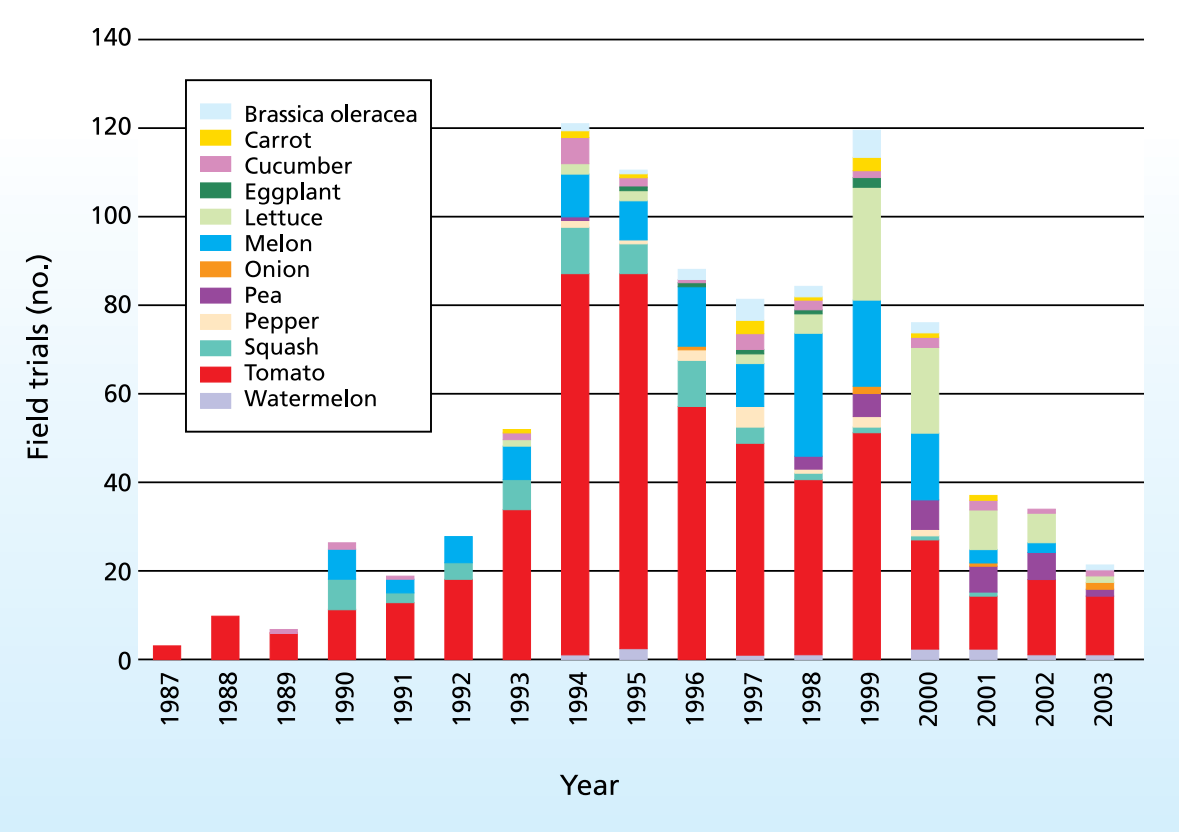

Fig. 2. U.S. field trials of biotech fruits and vegetables, 1987 to 2003. (Brassica oleracea includes broccoli, cauliflower, kale, cabbage and Brussels sprouts.) Source: http://www.nbiap. vt.edu/cfdocs/fieldtests1.cfm.

had planted the New Leaf potato (see sidebar, page 94). Research activities with horticultural crops have also been cut back, with the number of field trials conducted declining since 1999 (fig. 2). Together, the E.U. moratorium, the failure of the European Union to establish tolerances for the adventitious (accidental) presence of biotech crops in food and seed, labeling issues and the reluctance of the marketing chain to accept new biotech foods have virtually halted commercialization of new biotech fruits and vegetables.

\section{Crops approved as safe}

Despite initial consumer acceptance, biotech horticultural products are virtually absent from today's market. Are U.S. consumers concerned about the safety of these products? They do not appear to be, since they trust the U.S. government's oversight. The regulatory requirements to demonstrate food, feed and environmental safety of biotech crops are well established in the United States. The U.S. Department of Agriculture (USDA) Animal and Plant Health Inspection Service
(APHIS) regulates the field testing and commercial release of genetically engineered (GE) plants; the U.S. Environmental Protection Agency (EPA) ensures the safety and safe use of pesticidal and herbicidal substances in the environment; and the U.S. Food and Drug Administration (FDA) governs the safety and labeling of the nation's food and feed supply (APHIS 2002).

Extensive safety data are generated for each specific transformation event (the insertion of a specific segment of recombinant DNA into a specific variety). In general, it takes dozens or hundreds of transformation events, each of which must subsequently be regenerated into a transgenic plant, to identify one or two that will be used for commercialization. This compares to the hundreds or thousands of plants that may be evaluated in a traditional breeding program to identify a single commercial line. However, unlike with traditional breeding, each commercial transformation event must have its own dossier of safety assessments and meet key data requirements, including toxicity, nutritional data, allergenicity and environmental impacts (see box, page 108).

Companies have conducted these studies for all biotech products commercialized to date, and U.S. and international regulatory agencies have granted 
approvals (see box, page 109). No case has been documented to date of harm to humans or the environment from the biotech crops currently being marketed, although "genetic drift" from transgenic to conventional crops has occurred as it has for millennia between conventional crops. Now some Mexican growers have expressed concerns under the North American Free Trade Agreement (NAFTA) about preserving the biodiversity of their maize due to gene flow from transgenic corn (NACEC 2004).

Certainly, information of this type is needed to identify potential hazards and ensure the food and environmental safety of crops developed using biotechnology. Despite the track record of currently approved biotech crops, many opponents continue to demand that additional safety studies be conducted due to concerns such as genetic drift, out-crossing with wild species and food safety. For example, the U.K. Royal Society (2002), an organization of distinguished scientists, made the following conclusions:

- "There is at present no evidence that GM foods cause allergic reactions."

- "There is no evidence to suggest that those GM foods that have been approved for use are harmful."

- "Risks to human health associated with the use of specific viral DNA sequences in GM plants are negligible."

- "It is unlikely that the ingestion of well-characterized transgenes in normal food and their possible transfer to mammalian cells would have any significant deleterious biological effects."

Nonetheless, in the same report, the Royal Society recommended that more studies be conducted using the latest analytical techniques to test each and every compound produced by the biotech crops, including compounds released as volatiles. The Royal Society then recommended that post-marketing
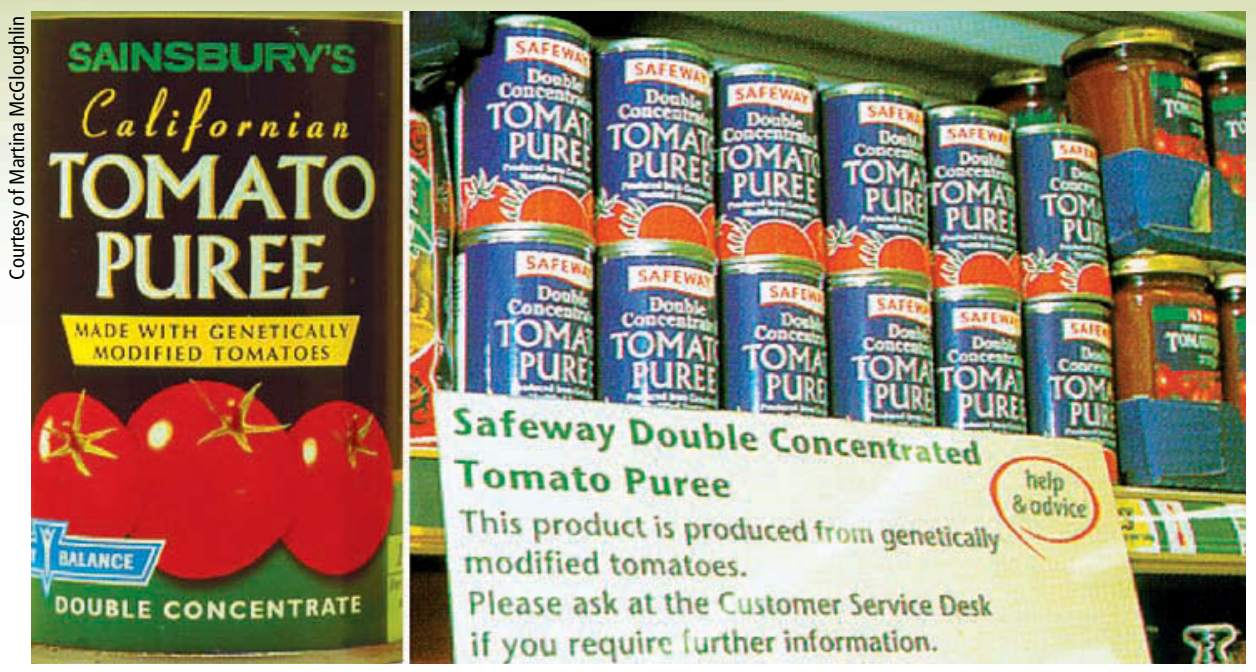

Zeneca's biotech tomato puree (paste) was successfully sold in the United Kingdom from 1996 to 2000.

surveillance be conducted, "should GM foods be reintroduced into the market in the U.K." Although it could not identify any specific safety hazards in current biotech products, the Royal Society did not recommend that such foods be allowed back into the United Kingdom. Regardless of the extent of safety testing and absence of evidence of harm, the bar may continue to be raised as new testing technologies are developed, making it increasingly expensive to meet regulatory requirements.

\section{Regulatory and other barriers}

In addition to safety assessments, there are a number of significant barriers to developing new biotech horticultural crops, including the added costs of variety development, regulatory approval, post-commercialization stewardship and the reluctance of the horticultural marketing industry to accept products grown from biotech varieties. Many of the hurdles faced by companies developing biotech varieties do not exist for traditionally bred varieties, including the following issues.

\section{Seed movement and field testing.} Experimental biotech varieties can be moved interstate and tested in the field only under permit from the APHIS, to prevent mixing with nonbiotech seed. During the experimental phase, it takes at least 10 days to obtain a permit for seed movement and 30 days to obtain one for field release.

Adventitious mixing. Specific protocols must be developed, implemented and enforced to prevent adventitious
Key data requirements for U.S. safety assessments of new transgenic crops

Product description: data on the host or parent plant, introduced or novel genetic material, and intended effect of the inserted gene.

Molecular characterization: data on the location and manner in which the target gene is inserted into a single site in the host plant's DNA.

Toxicity studies: as necessary, tests demonstrating the safety of the transgenic protein.

Nutritional data: analyses of the fruit or commodity collected over several growing environments and growing seasons.

Substantial equivalency: data and information showing that the biotech variety differs from comparable nonbiotech varieties only with respect to the intended effect.

Allergenicity: analyses showing that a transgenic protein is unlikely to cause al-

Natural toxicants: analyses showing that there is no increase in the levels of natural toxicants.

Environmental impact: studies demonstrating that the biotech variety is unlikely to have an adverse effect on the environment, including:

- Outcrossing and gene flow, to evaluate whether the introduced trait is likely to move from the crop to related wild species.

- Germination and flowering, to determine whether the introduced trait is likely to alter seed germination, flowering time or other properties that affect the plant's ability to reproduce in the wild. lergic reactions in humans. 


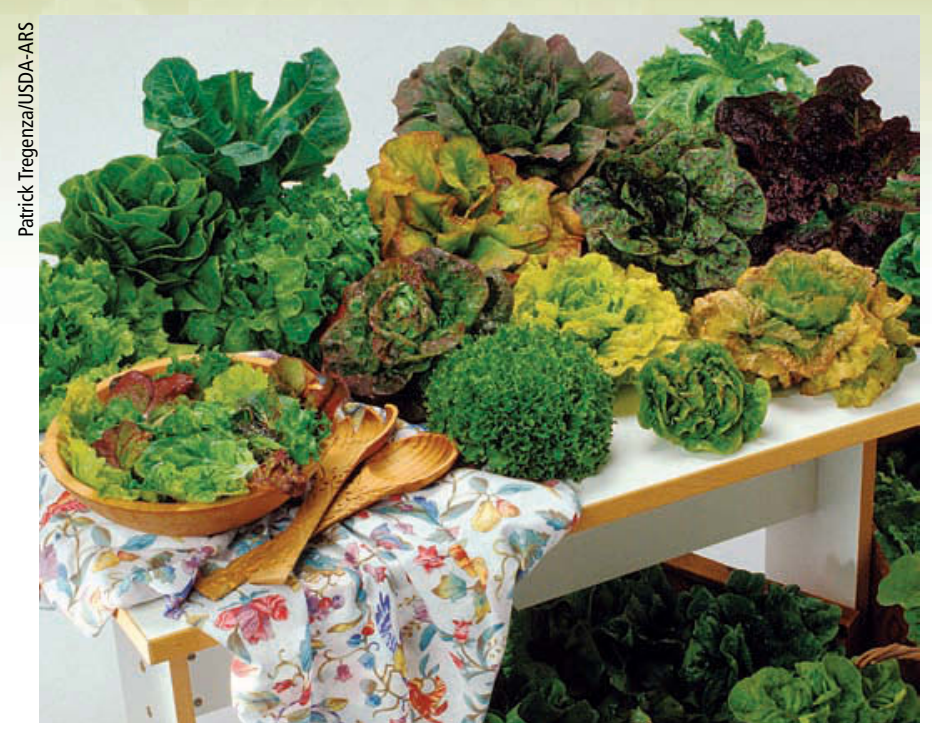

There are often dozens of varieties for a particular horticultural crop. Above, seeds of the world's most unusual lettuces are safeguarded in an ARS gene bank in Salinas. Genetically engineered lettuce has not been commercialized.

mixing with other varieties. Such mixing can occur as a result of pollen movement from a biotech field to a conventional field or during seed harvest and cleaning. Adventitious mixing occurs when very small amounts of biotech seed mix with other nonbiotech seed. Regulatory agencies in some countries establish "tolerances," the maximum allowable amount of adventitious material (similar to tolerances for pesticide residues). For biotech varieties at the experimental stage (unapproved events), the tolerances are usually zero in food and seed. For biotech varieties approved for commercial growing and consumption, the thresholds for adventitious presence vary from country to country, ranging from less than $1 \%$ to $5 \%$ for food ingredients, and $0.3 \%$ to $1 \%$ for seed. By comparison, conventional seed-purity thresholds are usually between $1 \%$ and $10 \%$, depending on the crop and varieties.

Handling procedures. Separate breeding and seed production programs are needed for biotech crops, with increased isolation and strict handling procedures to prevent cross-pollination or adventitious mixing. Increased seed purity standards - over the standards for conventional seed - are also required throughout growing, harvesting, cleaning, milling, storage, coating, packaging and shipping.

Tracking, training. In order to achieve tolerances an order of magnicrop.

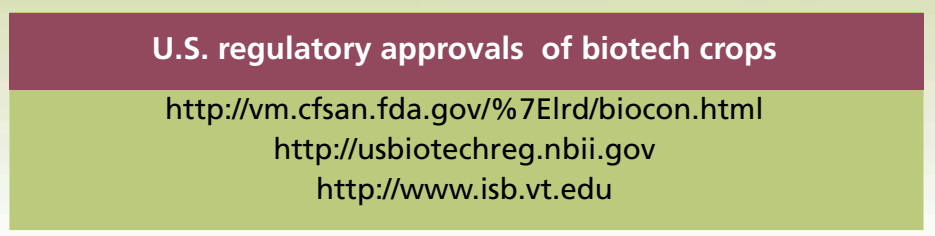

tude stricter for biotech varieties than is required for conventional varieties, biotech-specific internal tracking and testing procedures must be implemented. Additional training on handling of biotech crops is required throughout the development and marketing chain - from molecular biologists and breeders to seed producers and distributors. Each new employee who might be involved with biotech varieties at any level must be specially trained. Depending upon the type of product, grower training and post-commercialization stewardship programs may be required.

\section{Increased development costs}

These additional requirements have increased the cost of developing biotech varieties (in excess of costs to develop traditionally bred varieties) to at least $\$ 1$ million per allele (if limited strictly to the United States) and more likely to $\$ 5$ million or more per allele, depending on the number of countries in which approvals are required. An allele is a single transformation event, which contains the genetic trait of interest and expresses the desired phenotype in the

These additional costs and issues are the same for both field and horticultural crops. Due to the large acreage of field crops, the costs can be justified by the market size of the biotech varieties. The same is not true for horticultural crops because of the small acreage of each crop. One strategy has been to limit marketing of a biotech horticultural crop to just the United States. However, due to the international trade in horticultural commodities, there are few examples of products under development in which both the seed and the product could be contained solely in the United States. More likely, a biotech variety will need approvals in a number of countries to which the product might be exported. For example, biotech processing-tomatoes grown in California will end up being exported as tomato paste or other products to many countries around the world, each of which must give food approval prior to commercialization. And, if the processed product contains seeds that might be viable, environmental studies and approvals are also be required in the importing country, even if the importation is intended only for food consumption. Importing countries may also impose additional and unique requirements, such as labeling or the ability to trace the product back to the producing farm, as in pending E.U. regulations.

The end-result of a successful biotech development program is a new allele that produces the intended effect, has passed the thorough safety testing and has received approvals and registrations from appropriate government agencies. In the 1990s, developers of biotech varieties assumed that once a biotech product was shown to be safe, it would be produced and marketed just like any other commodity. A biotech allele would be equivalent to a traditional allele, and there would be no need for product segregation, labeling or special handling. While this is largely the case in the United States, this assumption is no longer valid because of labeling requirements in the European Union and other countries.

Another assumption was that product approvals could be achieved generically for a specific gene and crop. That is, once a particular gene product was shown to be safe, it could be introduced into additional varieties without retesting. Instead, approvals are based on specific transformation events. Consequently, if different varieties are transformed with a given gene to produce a - continued on page 111 


\section{IR-4 Project targets specialty crops}

\author{
Robert E. Holm \\ Daniel Kunkel
}

Pestate esticide applications for "minor" or "specialty" crops - typically those grown on less than 300,000 acres nationwide - often do not get the full support of product registrants because the potential economic benefits are perceived as much more limited than for applications targeting crops grown on large acreages, such as soybeans and field corn. The IR-4 Project is a unique partnership of researchers, producers, the crop-protection industry and federal agencies designed to increase pest-management options for specialty crops, which include vegetables, fruits, nuts, herbs, nursery crops and flowers. (Most of the crops grown in California fit into this category.)

With funding from the U.S. Department of Agriculture, state agencies, commodity groups and other industry sources, IR-4 researchers and cooperators generate field and laboratory residue data, which are submitted to the U.S. Environmental Protection Agency (EPA) to secure regulatory clearances for using safer pest-control techniques on specialty crops. Projects are prioritized based on requests from growers, commodity groups, and USDA and land-grant university researchers. Since 1963, IR-4 has contributed to more than 7,300 regulatory clearances for specialty crops. initiated a pilot program to support new transgenic horticultural crops. Because they are also grown on smaller acreages, transgenic horticultural crops face many of the same regulatory hurdles as uses on conventional specialty crops.

\section{Focus on herbicide tolerance}

The IR-4 team initially identified herbicide tolerance and insect resistance as potential opportunities for assisting transgenic specialty crops through the regulatory review process. It then narrowed down the focus to herbicide tolerance, recognizing that the FQPA could possibly limit the use of several key herbicides for vegetables due to regulatory concerns about toxicology and groundwater contamination. The other justification for focusing on herbicide tolerance was that the newer herbicides in the development pipeline for major crops had limited tolerance on specialty crops, prompting companies to restrict their uses on vegetables due to product liability concerns.

Sweet corn. IR-4's first transgenic project was the result of research conducted by Gordon Harvey at the University of Wisconsin, who was looking

\section{The IR-4 Project is a unique partnership of researchers, producers, the crop protection industry and federal agencies de- signed to increase pest-management options for specialty crops.}

In 1996, IR-4 responded to the federal Food Quality Protection Act (FQPA) by shifting its strategy from product defense (support for older pesticides needing reregistration) to working with reduced-risk/safer chemistries and biopesticides. The program also expanded its Good Laboratory Practices (GLPs) efforts, started a Methyl Bromide Alternatives Program and for alternatives to the use of atrazine - a potential groundwater contaminant - in Wisconsin sweet-corn production. Harvey conducted studies on glufosinate-tolerant (Liberty Link) sweet corn and demonstrated excellent weed control. The commercial varieties linked the Bt gene with the glufosinate-tolerant gene to provide additional protection against corn borer and corn earworm, two major sweet-corn pests.

IR-4 then facilitated the residue assessment programs required by EPA in 1997, 1998 and 1999. As a result, EPA granted Section 18 "emergency use" permits for the herbicide-tolerant sweet corn in Wisconsin, Minnesota and Michigan in 1999 and 2000. However, due to concerns about consumer acceptance expressed by sweet-corn processors, no significant commercial acreages of these varieties were planted in 2001 and 2002. Nonetheless, IR-4 submitted a complete registration package to EPA for glufosinate-tolerant sweet corn in 2003.

Lettuce. IR-4's other herbicide transgenic project was glyphosatetolerant (Roundup Ready) lettuce. IR-4 staff met with Seminis Vegetable Seeds (licensee of transformation technology) and Monsanto (glyphosate registrant and gene technology licensor) in 1998 to discuss potential technology applications. The project was placed on the IR-4 30-month "fast track," with submission to the EPA scheduled for 2001. The program was a cooperative partnership between Seminis Vegetable Seeds (seeds and technology support), Monsanto (residue analysis and technical support) and IR-4 (field residue program, project management 
and petition preparation and submission).

However, in 2000 several grower groups expressed reservations about the program primarily due to concerns about public acceptance, leading the partners to slow the program down. During this period, field results from several university researchers demonstrated excellent weed control in glyphosate-tolerant lettuce, resulting in reduction of hand-hoeing costs. It is still not certain when or if IR-4 will submit a registration package to EPA.

\section{Future directions}

IR-4 cannot take on additional specialty-crop biotechnology projects without new funding from the USDA (Agricultural Research Service and Cooperative State Research,

Education, and Extension Service) and support from IR-4 management and stakeholders. Current funding is just adequate to cover the existing core programs of reduced-risk chemistries, biopesticides, ornamentals and methyl bromide alternatives. Additional funding from Congress or other sources (either public or private) would be necessary. IR-4's core competencies are in field residue studies and chemical laboratory analyses conducted under GLPs. Safety and environmental testing on specialty crops, especially allergenicity testing of newly expressed proteins in transgenic crops, is well beyond IR-4's existing capabilities.

Under current and proposed regulatory guidelines, the best approach for such testing might be to seek approval first in major acreage row crops such as corn, cotton, soybeans and rice, and allow those approvals apply to specialty-crop uses, as was the case for Bt sweet corn following the approval of Bt field corn. Of course, this approach is limited to traits that are applicable in both agronomic and horticultural crops, and will likely exclude many traits directed toward output quality.

IR-4 management and stakeholder support issue is even more difficult, as they are not in unanimous support of developing agricultural biotechnology, principally due to consumer concerns in Europe and to a lesser extent the United States. In the future, the IR-4 framework could be useful to address the pest-control needs of horticultural and other specialty crops via plant biotechnology, once a consensus is reached that they are cost-effective and safe for the environment and consumers.

\footnotetext{
R.E. Holm is Executive Director and D. Kunkel is Assistant Director, IR-4 Program, North Brunswick, N.J.
}

range of biotech varieties, each is an independent transformation event subject to all of the regulatory requirements. Because this is prohibitively expensive, developers must transform just one variety, register that event, and then use traditional breeding methods to incorporate the transgene into other varieties. This greatly delays and increases the cost of developing multiple biotech varieties in a given crop. This is particularly restrictive for horticultural crops, in which many varieties are required to meet different seasonal production requirements and diverse consumer preferences, and any single variety has a relatively small market share. For example, dozens of different types and varieties of lettuce (such as iceberg, romaine, leafy) are grown throughout the year as production shifts between summer and winter locations in California, Arizona and Florida.

Some agronomic seed companies budget $\$ 50$ million for the full commercialization of a new biotech crop, in addition to the standard costs for developing and marketing a traditional variety. Given the small acreage of horticultural crops and their much lower overall value, it is difficult to justify the investment in transgenic horticultural crops. For example, the total U.S. market for iceberg lettuce seed is about $\$ 27$ million. A typical single variety is worth about $\$ 150,000$ to $\$ 250,000$ during its 5-year market lifetime, which suggests that garnering a large market share of lettuce varieties with significant added value would be necessary in order to pay for the additional costs imposed on biotech varieties.

\section{Commercialization opportunities}

Despite this gloomy picture, regulatory strategies may be possible that would protect public and environmental safety while decreasing the cost of introducing biotech specialty crops (Strauss 2003). Plant breeding companies employing biotechnology can manage and reduce regulatory costs by carefully and deliberately - continued on page 114 


\title{
China aggressively pursuing horticulture and plant biotechnology
}

\author{
Jikun Huang \\ Scott Rozelle
}

\begin{abstract}
AS the world debates the costs and benefits of plant biotechnology, swinging between optimism generated by a long list of breakthroughs and pessimism caused by a consumer backlash in some places, a new source of plant biotechnology discoveries is emerging in a most unlikely place: China. And the discoveries being made are more than cosmetic transformations. China's research community has made a major investment into understanding the structure and function of the rice genome, the use of agrobacterium to transform the rice plant, and new methods of transforming other crops, including a wide array of horticultural plants.

China has one of the largest and most successful agricultural research systems in the developing world (Stone 1988). Historically, much of China's research was focused on grain, and the government invested in research and development (R\&D) as part of its pursuit of food self-sufficiency. Horticulture played only a small role in China's development strategy.

Economic growth, the rise of markets and the opening up of China's economy have resulted in a sharp shift in government policy and pro-
\end{abstract}

ducer decision-making. As markets emerged in the 1990s, farmers reduced their area sown to traditional grain and fiber crops and began to cultivate vast tracts of produce. Fruit and vegetable area has nearly doubled in China, expanding by more than 20 million acres during the 1990s, adding the equivalent of a "new California" every 3 years for the past 12 years.

The Chinese research system has responded to the new demands. In the mid1990s, top research administrators began allocating more funds to nontraditional crops. Researchers, including those in a nascent privatesector seed company, were given more freedom to work on broader array of crops and provided with incentives to shift to horticultural crops.

Research in modern plant biotechnology began in the mid-1980s. Chinese scientists now apply advanced biotechnology tools to plant science,

\begin{tabular}{llccc} 
TABLE 1. Field trials, environmental releases and commercialization \\
of genetically modified horticultural plants in China through 2000 \\
\hline \hline Crop & Introduced trait & $\begin{array}{c}\text { Field } \\
\text { trial }\end{array}$ & $\begin{array}{c}\text { Environmental } \\
\text { release }\end{array}$ & $\begin{array}{c}\text { Commer- } \\
\text { cialized }\end{array}$ \\
\hline Cabbage & $\begin{array}{l}\text { Turnip mosaic virus resistance } \\
\text { Cauliflower mosaic virus } \\
\text { Tomato }\end{array}$ & Yes & No & No \\
& (CMV) resistance & Yes & Yes & Yes \\
& $\begin{array}{l}\text { Tobacco mosaic virus } \\
\text { (TMV) and CMV resistance }\end{array}$ & Yes & No & No \\
& Shelf-life altered & Yes & Yes & Yes \\
& Cold tolerance & Yes & Yes & No \\
Melon & CMV resistance & Yes & No & No \\
Sweet pepper & CMV resistance & Yes & Yes & Yes \\
Chili & CMV and TMV resistance & Yes & Yes & No \\
Papaya & Papaya ringspot virus resistance & Yes & Yes & No \\
Petunia & Flower-color altered & Yes & Yes & Yes \\
Pogostemon* * & Bacteria wilt resistance & Yes & No & No \\
\hline
\end{tabular}

Source: Author survey.

*An Asian shrub, used to make patchouli oil for fragrances and medicinal purposes.

regularly working on the synthesis, isolation and cloning of new genes, and the genetic transformations of plants. Our survey of China's plant biotechnology laboratories identified more than 50 plant species and more than 120 functional genes that scientists are using in genetic engineering, making China a global leader. China's scientists have generated an array of technological breakthroughs in transgenic plants and animals (Huang et al. 2002), and are currently working on a large number of horticultural crops such as tomatoes, melons and peppers (table 1).

The technologies that have been approved for commercial release also demonstrate China's ability to move ahead with its biotechnology program. Among the varieties approved and licensed for commercialization before 2000 were shelf-life-altered tomatoes, color-altered petunias and pest-resistant peppers. Although approvals for genetically modified (GM) food crops have slowed recently, China was allocating about $9 \%$ of its research budget to plant biotechnology in 1999. In the late 1990s, China accounted for more than half of the developing world's expenditures on plant biotechnology. Recently, officials announced a plan to drastically raise research budgets.

Many issues face China's research administrators. China's government recently put into place a regulation and biosafety system, but it is new, underfunded and has not proven its ability to enforce regulation. Chinese leaders are struggling with issues of consumer safety and acceptance, both within their own country and in countries that import its farm commodities. Almost nothing is known about how 
determining the necessary testing requirements. Costs can be reduced by focusing development on biotech genes that have already been commercialized in agronomic crops, since expensive toxicity studies done on a new protein produced in a biotech agronomic crop can be used for the same protein produced in a biotech horticultural crop.

The USDA IR-4 program conducts and pays for the collection of efficacy and safety data on pest-control chemicals for "minor" or "specialty" crops, which include most horticultural crops (see sidebar, page 110). A new, expanded "biotech IR-4" program focused on full crop registration, including EPA, USDA and FDA requirements, could benefit horticultural crops being developed in universities, government laboratories and small companies. This is particularly critical for the next generation of transgenic products, which will be more consumer-oriented and specific to horticultural crops. Because horticultural products in the pipeline are likely to have altered nutritional or quality traits, specific safety tests will be required that cannot rely on data generated for agronomic crops. Without a program like IR-4, testing requirements could preclude such products from ever being developed and reaching the market.

As demonstrated by Calgene and Zeneca with their early tomato products, consumers are receptive to labeled products that have clear quality or price benefits. However, focusing entirely on consumer-oriented traits would forgo valuable benefits for crop production, such as virus resistance, which could have enormous advantages for producers that would not be readily recognized by consumers. As further experience is gained with biotech methods, regulatory requirements should be relaxed for categories of products posing little health or environmental risk. In addition, generic crop and gene approvals (such as glyphosate-resistance approval for all alleles in all leafy vegetables), rather than the current "event-specific" approach (separate approvals for each

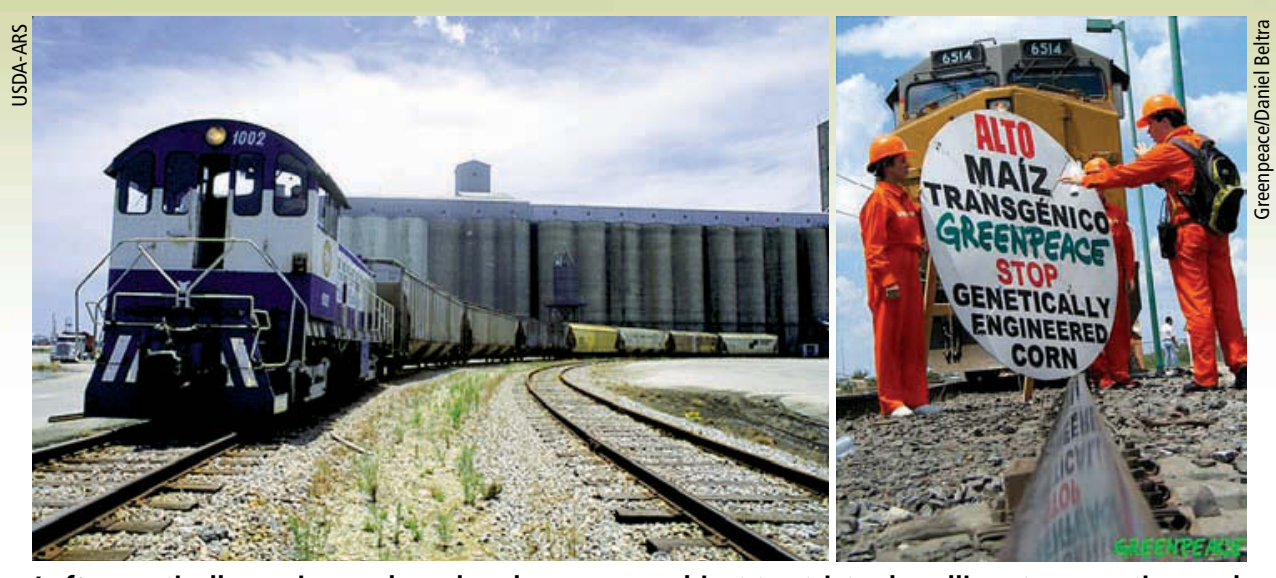

Left, genetically engineered seed and crops are subject to stricter handling, transporting and tracking procedures to prevent cross-pollination and adventitious (accidental) mixing with conventional crops. The presence of Starlink corn in food products showed that there were weaknesses in the ability to segregate grains on their way to market. Right, in August 2003, Greenpeace activists blocked a trainload of biotech corn as it attempted to cross the Rio Grande into Mexico, claiming that it threatened native land races of maize.

allele in each vegetable), would do much to encourage further development of such products.

Around the world, farmers desire and in some cases, demand the benefits that can come from the improved varieties. In India, for example, extensive precommercialization field trials of insect-resistant cotton found average yield increases of $80 \%$ along with a $68 \%$ reduction in insecticide use (Qaim and Zilberman 2003). Farmers saw the value of the varieties and grew 25,000 acres of insect-resistant cotton in 2001, prior to government approval (in 2002). Similarly, a significant percentage of soybeans in Brazil was grown from herbicide-resistant seeds smuggled into the country from Argentina and propagated by farmers, as Brazilian courts held up their release despite governmental approval. While planting of insect-resistant corn has not been approved in Mexico, Mexican workers returning from the United States have brought back seed corn for planting, and biotech food grain sold in Mexico has also been planted. At the 2002 Institute of Food Technologists' annual meeting, E.C.D. Todd of Michigan State University reported that Thai farmers are smuggling and planting biotech seeds from China. While the distribution of biotech varieties outside of legal channels cannot be condoned, these examples illustrate that farmers are aware of the advantages these varieties can deliver. As research continues at many companies, universities and government laboratories, biotech horticultural products having similar attractions for growers and consumers (see page 89) may overcome the current financial and logistical hurdles facing their commercial development.

\section{Future prospects; biotech in China}

Despite vocal opposition, agricultural biotechnology continues to advance. China has made significant strides in commercializing GE horticultural crops over the past 10 years and may well become the world's leader during the next 10 years (see sidebar, page 112). China was the first country to commercialize biotech plants, beginning with field production of thousands of acres of virusresistant tobacco in 1988 , followed by virus-resistant tomatoes (500 acres) and sweet pepper (6 acres) in 1994 (Chen and Zhu 1994; Rudelsheim 1994; Zhou et al. 1994; Stipp 2002). In the mid-1990s, China was criticized by an American delegation for having only a provincial and not a national product-approval system. For several years afterward, it was difficult to determine whether further commercial plantings of biotech crops occurred in China (Redenbaugh et al. 1996).

Interestingly, China established 1997 as the "official" commercialization date for biotech cotton, tomato, sweet pepper and petunia, which is when the crops were authorized by the agricultural-biotechnology safety office of the Chinese Ministry of Agriculture (Z. Chen, personal communication, LMOs \& the Environment Conference, Durham, NC, 2001). Chi- 


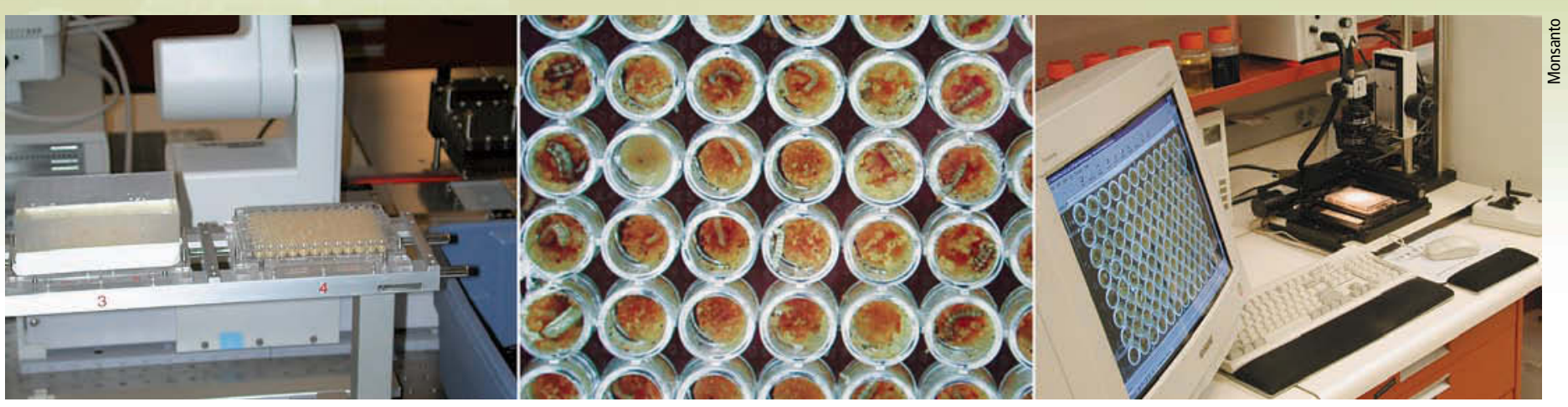

Many of the biotech crops on the market today are genetically engineered for insect resistance. At Monsanto's laboratory in St. Louis, proteins are screened, left and right, for insecticidal activity. In the

micro-wells, center, the insect eggs or larvae of the target species are placed in protein material that is incubated for several days and then examined for survival or growth of the insect.

na currently claims to be second only to the United States in agricultural biotech research, development and cultivation, and China is taking full advantage of uncertainty caused by the European Union's stance on biotech approvals. Beijing University vice president Chen (1999) stated, "I expect that in 10 years between $30 \%$ and $80 \%$ of the rice, wheat, maize, soya, cotton and oilseed crops in China will be transgenic crops. We can take advantage of this 4-year halt [E.U. moratorium] to turn China into a world power in genetically modified organisms."

China is in an excellent position to develop and create internal markets for biotech horticultural crops and clearly has the opportunity to surpass the United States in biotech crop development. Recently, China erected barriers to the importation of biotech grains, creating confusion for U.S. and world exporters, while backing away from some of its earliest commercial biotech products (Macilwane 2003). It is not known whether this is due to internal concern over biotech products or fear of jeopardizing its own export markets to Europe, or is a trade barrier to allow for additional internal development of biotech products. Greater clarity will occur should this issue come before the World Trade Organization (WTO).

Regulatory issues and costs are reducing commercial opportunities for new biotech crops in the United States. Of course, China will need to meet the requirements of any country receiving their exports, but currently it is unclear whether any of China's biotech products are being exported. Korea and Japan are not likely to press this as a trade issue. Other internal political issues are currently complicating commercialization efforts within China, but these are likely to be only short-term barriers (Economist 2002).

While the United States falters over biotech fruits and vegetables, China is positioning itself to be the world leader in coming years. For the American horticultural industry, the results could be devastating if the United States loses its current competitive edge and more agricultural production moves overseas.

K. Redenbaugh is Associate Director, Seminis Vegetable Seeds, Woodland; and A. McHughen is Plant Biotechnologist, Department of Botany and Plant Sciences, UC Riverside.

\section{References}

[APHIS] Animal and Plant Health Inspection Service. 2002. U.S. Regulatory Oversight in Biotechnology Responsible Agencies - Overview. www.aphis.usda. gov/ppq/biotech/usregs.html.

Bruening G, Lyons JM. 2000. The case of the FLAVR SAVR tomato. Cal Ag 54(4):6-7.

Chen Z. 1999. Unlimited prospects for biotechnology. Knowledge Econ [Zhishi Jingji]. December. p 22-8.

Chen A, Zhu Y. 1994. Summary of field release of transgenic tobacco, tomato and sweet pepper. In: Proc 3rd Intl Symp, Biosafety Results of Field Tests of Genetically Modified Plants and Microorganisms, Monterey, CA. UC DANR, Oakland, CA. $p$ 229-31.

Cornell Cooperative Extension. 2003. Am I eating GE potatoes? Genetically Engineered Organisms: Public Issues Education Project. www.geo-pie.cornell.edu//crops/ potato.html (accessed 3/16/04).

Economist. 2002. Biotech's yin and yang - Growing fast, but facing several chal- lenges. Dec 14. p 75-7.

Ferreira SA, Pitz KY, Manshardt R, et al. 2002. Virus-coat-protein transgenic papaya provides practical control of papaya ringspot virus in Hawaii. Plant Dis 86:101-5.

Gianessi LP, Silvers CS, Sankula S, Carpenter JE. 2002. Plant Biotechnology: Current and Potential Impact For Improving Pest Management In U.S. Agriculture; An Analysis of 40 Case Studies. National Center for Food and Agricultural Policy. www.ncfap.org/40CaseStudies.htm.

James C. 2003. Global status of commercialized transgenic crops. ISAAA Briefs No 30. www.isaaa.org.

Macilwane C. 2003. Against the grain. Nature 422:111-2.

[NACEC] North American Commission for Environmental Cooperation. 2004. Maize and biodiversity: The effects of transgenic maize in Mexico. www.cec.org/ maize/index.cfm?varlan=English (viewed 3/17/04)

Qaim M, Zilberman D. 2003. Yield effects of genetically modified crops in developing countries. Science 299:900-2.

Redenbaugh K, Malyj L, Lindemann J, Emlay D. 1996. Commercialization of biotechnology products. Proc N Am Plant Protect Org, Saskatoon, SK, Canada.

Royal Society. 2002. Genetically Modified Plants for Food Use and Human Health - An Update. Royal Society, London, UK. www.royalsoc.ac.uk/gmplants.

Rudelsheim P. 1994. Experiences in approaching commercialization of transgenic crop plants. In: Proc 3rd Intl Symp, Biosafety Results of Field Tests of Genetically Modified Plants and Microorganisms, Monterey, CA. UC DANR, Oakland, CA. p 323-5.

Schmitt B. 2002. Conventional agchems decline, but biotech products boom. Chem Week 164:33.

Stipp D. 2002. China's biotech is starting to bloom. Fortune (Sept 2):126-34.

Strauss SH. 2003. Genomics, genetic engineering and domestication of crops. Science 300:61-2.

Zhou R, Zhang Z, Wu Q, et al. 1994. Large-scale performance of transgenic tobacco plants resistant to both tobacco mosaic virus and cucumber mosaic virus. In: Proc 3rd Intl Symp, Biosafety Results of Field Tests of Genetically Modified Plants and Microorganisms, Monterey, CA. UC DANR, Oakland, CA. p 49-55. 